\title{
Analysis of Reading Habits in Secondary Education in Extremadura
}

\section{Análisis de los hábitos de lectura en la Educación Secundaria en Extremadura}

José Soto Vázquez (*) https://orcid.org/0000-0002-9967-5694

Francisco Javier Jaraíz-Cabanillas (*) https://orcid.org/0000-0003-3575-3136

José Antonio Gutiérrez-Gallego (*) https://orcid.org/0000-0002-2375-7087

Ramón Pérez-Parejo (*) https://orcid.org/0000-0002-7802-979X

(*) Universidad de Extremadura

(Received: February 11, 2020; accepted for publishing: June 19, 2020)

How to cite: Soto-Vázquez, J., Jaraíz-Cabanillas, F. J., Gutiérrez-Gallego, J. A. y Pérez-Parejo, R. (2021). Analysis of reading habits in secondary education in Extremadura. Revista Electrónica de Investigación Educativa, 23, e19, 1-20.

https://doi.org/10.24320/redie.2021.23.e19.3857

\section{Abstract}

This study aims to discern the reading habits of secondary education students of the autonomous community of Extremadura (Spain). A survey was conducted with 4,392 students throughout the region. Their reading habits were analyzed in relation to time spent reading, book purchases, preferred literary genres, and other variables that may influence reading habits. By determining the geographic location of respondents, it became possible to map the variables. Key conclusions include clear differences between geographical areas, together with the following findings: women read somewhat more than men; students enrolled in bilingual programs read more; following specific reading plans has no impact on achieving better reading outcomes; despite the increase in digital reading, paper books are still read more; and reading is not perceived as a leisure activity.

Keywords: reading, inequality, secondary education, library

\section{Resumen}

Este estudio pretende conocer los hábitos de lectura de los alumnos de educación secundaria de la comunidad autónoma de Extremadura (España). Se realizó una encuesta con 4,392 alumnos en toda la región. Se analizaron sus hábitos de lectura en relación con el tiempo dedicado a la lectura, las compras de libros, los géneros literarios preferidos y otras variables que pueden incidir en los hábitos de lectura. Al determinar la ubicación geográfica de los encuestados, se pudo realizar una representación cartográfica de las variables. Las conclusiones principales arrojan luz sobre diferencias evidentes entre zonas geográficas, junto con los resultados siguientes: las mujeres leen algo más que los hombres; leen más los alumnos inscritos en programas bilingües; la acogida a planes específicos de lectura no da lugar a mejores resultados de lectura; a pesar del aumento de la lectura digital, aún se leen más los libros en papel; y la lectura no se percibe como una actividad de ocio.

Palabras clave: lectura, desigualdad, enseñanza secundaria, biblioteca 


\section{Introduction}

Educational authorities invest large sums of money, offer courses, organize meetings, facilitate exchanges, and design programs to promote reading competency at schools on the basis that they "should provide all children, regardless of their achievement levels, with as many reading experiences as possible" (Cunningham \& Stanovich, 1998, p. 8). However, these initiatives are often ineffective because after the financial investment is made, the results are not properly analyzed in serious statistical evaluations so as to implement the appropriate political measures and educational investment strategies.

With a view to mitigating this shortcoming, this paper presents the reading habits of secondary school students in Extremadura (Spain). To do this, 4,392 surveys were administered at a total of 53 schools throughout the region. Reading habits were analyzed in terms of time spent reading, books purchased, preferred genres and other variables related to the use of social networks, library visits, bilingual education, how reading ranks among favorite hobbies, languages read, and reading habits and rates among students of foreign origin. All these variables were evaluated by respondents' sex, age, level of schooling and geographic агеа.

By determining the geographical location of the surveys, it was possible to map some of these variables. This could provide the starting point for implementing active policies to help improve reading competency rates in certain areas.

Certain hypotheses or research issues were taken as the central focus for presenting the results, and these are also discussed in the conclusions. First of all, there may be differences between areas in terms of reading habits in secondary school. Secondly, it is hypothesized that women read more than men, and thirdly, in principle, the specific measures offered by educational authorities (Spanish/English bilingual schools and departments based on AICLE [Content and Language Integrated Learning]), REBEX (School Library Network of Extremadura) and reading programs are expected to be effective. Other hypotheses include higher reading rates among students enrolled in ESO (compulsory secondary education) and in Baccalaureate (upper secondary education) courses ${ }^{1}$ than among those enrolled in vocational training, and differences between the reading habits of students of Spanish origin and those with immigrant backgrounds. Lastly, it is likely that other factors, such as library visits or perceptions, attitudes or beliefs surrounding reading as a leisure activity, have a positive impact on reading habits (Applegate \& Applegate, 2004; Asselin, 2000; Benevides \& Paterson, 2010; Daisey, 2009).

This aim and these hypotheses are reflected in the following research objectives: 1 ) to present the state of the art of previous statistical research on reading habits in Extremadura; 2) to describe the current reading habits of secondary education students in the Autonomous Community of Extremadura based on age, educational stage, school and sex (evaluating students' book purchasing habits, library use habits and literary preferences); and 3) to compare reading habits in secondary education based on sex, geographic area, educational stage, whether or not the education is at a bilingual school, school participation in regional or national reading programs, and nationality of origin.

To put the study area into its sociodemographic context, Extremadura is a region of southwest Spain, bordering Portugal, with an area of $41,635 \mathrm{~km}^{2}$ and a population of 1,079,720 as of January 1,2017. Due to its low per capita income, Extremadura is the only region in Spain to remain among the least developed in the EU for the 2014-2020 planning period, with a GDP per capita below 75\% of the average in Europe (Nieto \& Cárdenas, 2015), which has encouraged investment in education and research (Grecu et al., 2015; Mate \& Harris, 2013). Indeed, a PISA report (OECD, 2018) shows Extremadura is one of the regions with the worst results in the country.

For years, rural populations have been shrinking and losing infrastructure. Towns with fewer than 10,000 inhabitants account for $96 \%$ of the municipalities in Extremadura (Figure 1), while $50 \%$ of inhabitants live in

\footnotetext{
1 TN: In Spain, "compulsory secondary education" (educación secundaria obligatoria, ESO) refers to a cycle of four years of compulsory education from ages 12 to 16 years ( $7^{\text {th }}-10^{\text {th }}$ grades). The Spanish Baccalaureate (Bachillerato) consists of two optional additional years in high school (11 th and $12^{\text {th }}$ grades), which are required for students who wish to attend university.
} 
towns of more than 10,000 residents.

Figure 1. Population histogram by municipality

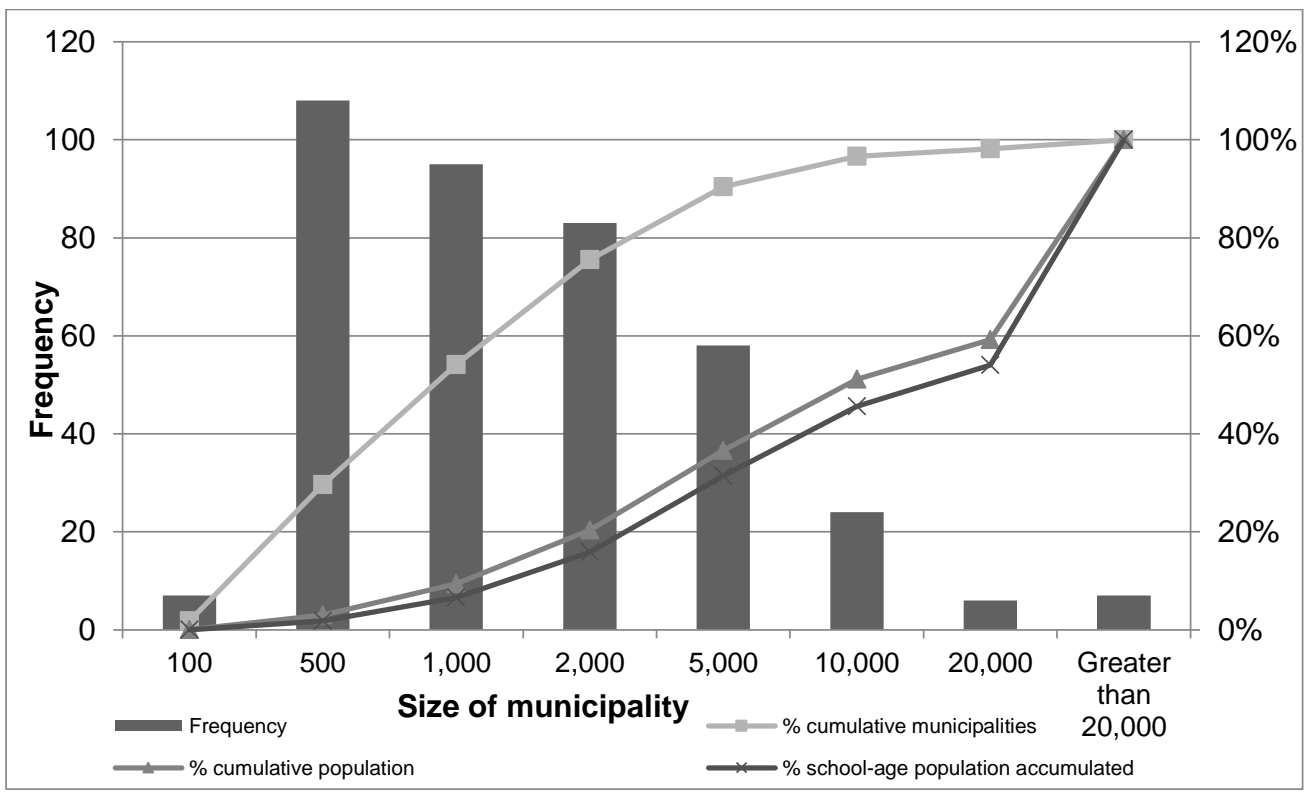

\subsection{Theoretical framework and state of the art}

One groundbreaking piece of work in sociological research on regional reading habits is a study by Olaziregi (2000, pp. 79-93) on secondary education in the Basque Country, comprising more than 3,000 surveys focused mainly on the reception of works of literary fiction in the Basque and Spanish languages. This study showed an increase in the quantity and quality of reading among adolescents, which had been confirmed previously in scholarly studies by Poulain (1988) and later by Moret (1999).

Another analysis that adds to the regional picture was conducted by the Germán Sánchez Ruipérez Foundation (Fundación Germán Sánchez Ruipérez, 2008) for the Program for Fostering Reading in Extremadura and centered on reading and book purchasing habits among Extremadurans aged 14 to 24. This report was based on research carried out in collaboration with the Ministry of Culture of the regional government of Extremadura starting in 2003. Some 600 surveys, broken down into age groups in the ranges of 14-17, 18-21 and 22-24 years, were conducted in towns with fewer than 10,000 inhabitants, those of 10,000 to 50,000 inhabitants, and those with larger populations. The substantial graphic material resulting from this study showed this regional increase with respect to data from the $20^{\text {th }}$ century, and also a greater reading frequency among women than men, with an average of 6.5 books per year.

Equally interesting are the conclusions reached by Gil (2009) in Andalusia, with data on 4,000 households through diagnostic tests. This study incorporates the family context, with cultural habits as a cornerstone for school performance. It focuses on the parents of students in the fifth year of elementary school (aged 10 or 11 years) and highlights the way in which the values and habits of family directly affect those of the children and the perception of reading as a cultural leisure activity.

Then 2009 saw the publication of Hábitos de lectura y compra de libros en Castilla-La Mancha [Reading and Book Purchasing Habits in Castile-La Mancha], once again authored by the Germán Sánchez Ruipérez Foundation (FGSR, 2009). Two years later, Muñoz and Hernández (2011) provided yet deeper insight with an article on reading habits in compulsory secondary education (ESO) in the province of Salamanca. Through 725 random surveys taken by young people aged 14 to 16 from both urban and rural settings, the study showed that, while reading is seen in a positive light, it is not a favorite pastime, and reading rates were higher among women than men. 
More recently, Serna et al. (2017) published work on school libraries and their potential for boosting the reading habits of students and families. Drawing on a total of 1,528 surveys among children aged 8 to 12 , it reaches the conclusion that school libraries must be promoted to improve reading habits given that their mere presence does not ensure or directly influence reading without promotional and integration campaigns.

In conclusion, there is currently a large, wide-ranging body of statistical work on this subject, consisting of regional studies on secondary education (Olaziregi, 2000; Muñoz \& Hernández, 2011), family participation (Gil, 2009), and the publishing industry and reading among immigrants (Pérez-Parejo et al., 2018a).

Since the last study of this kind in the region (Fundación Germán Sánchez Ruipérez , 2008) is now ten years old, it is a good time to revisit this topic in an attempt to understand the current situation and find possible ways to better implement programs to promote reading in light of the specific and unique features of Extremadura in 2017/2018.

Considering the international bibliography, with a focus on reading habits in adolescents, we note particular interest in the study of habits and their link to cognitive and psychological aspects (Brasseur-Hock et al., 2011; Duncan et al., 2016; Zebroff \& Kaufman, 2017). Likewise, there has been great interest in preparing assessment reports for foreign languages by institutions such as the Ministry of Education, Culture and Sport and the British Council (Dobson et al., 2010), as well as by other researchers (Corpas, 2014). It is a field of study that has gained relevance in recent years, mainly in specialized journals where quantitative, qualitative, methodological and/or comparatively diverse aspects related to reading competence are analyzed. Of particular note is a study by Coiro and Dobler (2007) that analyzes the impact of new technologies on reading habits, and research on types of cognitive skills for reading efficiency (Eason et al., 2012), reading motivation (Pitcher et al., 2007; Petscher, 2010), and the relationships between motivation to read and reading comprehension (Orellana et al., 2020; Stutz et al., 2016). These works are complemented by a comparison between the countries and sex of students and vehicular languages, in which these aspects were linked to students' socioeconomic status (Säälik, 2015), and other research focusing on gender differences in the reading processes of pre-adolescents (Logan \& Johnston, 2009, 2010; McGeown et al., 2012), which have been a constant focus of interest in our work.

Also interesting are studies that deal with the effect of other variables on reading habits, such as the amount read (Schaffner et al., 2013), readers' implicit models of reading (Schraw \& Bruning, 1999), teachers' implicit theories of learning to read (Jiménez et al., 2015), and, especially, teachers' own reading habits (Cremin et al., 2009; Granado, 2014), aspects that undoubtedly determine the results of any survey on this subject. In this regard, some statistical studies carried out in public elementary schools in Chile deserve a special mention. They focus on attitudes, reader profiles (Errázuriz et al., 2019) and prior conceptions of reading among both teachers (Errázuriz et al., 2020) and students (Fuentes et al., 2019). Some of the results of this study will be contrasted with this previous work in the discussion.

\section{Method}

Stratified two-stage sampling was employed to enable subsequent mapping of the variables. The study area was divided into two parts: on the one hand, the seven cities with populations of more than 20,000 inhabitants and, on the other, the municipalities were grouped into twelve main zones. In these twelve rural zones, the municipalities were classed in intervals by population size ( $<1,000$ inhabitants; from 1,000 to 2,000; 2,000 to 5,000; 5,000 to 10,000; and 10,000 to 20,000). Table I presents the study zones. 
Table 1. Study Areas

\begin{tabular}{ll}
\hline Rural Zones & Natural and/or functional districts included \\
\hline I & Las Hurdes, Sierra de Gata, Trasierra-Tierras de Granadilla, and Valle de Ambroz \\
II & Valle del Alagón, Rivera de Fresnedosa, and Riberos del Tajo \\
III & La Vera and Valle del Jerte \\
IV & Tajo Salor and Sierra de San Pedro \\
V & Las Villuercas-Ibores-Jara and Campo Arañuelo \\
VI & Comarca de Trujillo, Sierra de Montánchez, and Zona Centro \\
VII & Lácara Sur and Municipios Centro \\
VIII & La Serena-Vegas Altas and Guadiana \\
IX & La Serena and Siberia \\
X & Río Bodión, Tierra de Barros-Matachel, and Tierra de Barros \\
XI & Lácara-Los Baldíos, Comarca de Olivenza, and Sierra Suroeste \\
XII & Comarca de Llerena and Comarca de Tentudía \\
Urban Zones & Badajoz, Cáceres, Mérida, Plasencia, Don Benito, Villanueva de la Serena, and Almendralejo \\
\hline
\end{tabular}

In order to correctly conduct the study, a large number of information sources were consulted, ranging from censuses to stated preference surveys. The censuses were useful in defining the dimensions of the population being studied and properly stratifying the survey collection process.

The statistics office of the Educational Quality and Evaluation Department of the Secretariat-General for Education, pertaining to the Ministry of Education and Employment of the regional government of Extremadura, provided the spatial distribution of secondary school students in the region of Extremadura, which proved essential for the correct stratification of the surveys since it provided certain information not contained in the official censuses published by the Spanish National Statistics Institute (INE). Therefore, this is the main source of data used in the study to gather information about students enrolled in secondary schools, with a view to obtaining the sample size to conduct the surveys.

A census of students broken down by educational stage was needed to calculate the sample size to study reading habits among secondary school students. Likewise, to improve the mapping and graphical representation of the information extracted from the surveys, regardless of educational stage, information on the enrolled student population, broken down by town and student place of residence, was needed,. All information was also provided with a breakdown by sex.

The statistical unit for all variables was the individual secondary school student aged 12 or older attending the different kinds of schools at this educational level (compulsory secondary education institutes [IESO] and secondary education institutes [IES]). The biographical variables examined were sex, age, nationality, educational stage, school, province of residence and municipality of residence. The variables employed in relation to reading habits were the number of books read per month, reason for reading, time spent reading, frequency of library visits, favorite literary genres, reading format, reading in free time, language read, use of social networks, and book purchases.

The opinion poll was conducted by sampling the students present at the time of the survey in schools across the entire study area.

The data were collected directly from the sample units at the schools in hard copy format (on paper). An indirect collection method was also available, with data received in a worksheet generated by the Google Drive form application after the surveys had been correctly completed with guidance from teachers/survey takers, but this second collection method had very little impact. Ultimately, a total of 4,194 valid surveys were taken from a population of 75,670 secondary school students.

The survey was conducted from February to June 2017. The days were chosen based on the geographic location of the municipalities in the twelve rural zones drawn up within the study area and the municipalities 
not included in these zones (towns with more than 20,000 inhabitants). Within the twelve rural zones, one municipality was selected for each population interval, and students of all educational stages present were surveyed, provided there was a secondary school there.

The population figure in the region was taken into account and the corresponding number of surveys needed for each group of municipalities was calculated, as shown below.

The sample base was the total population of secondary school students in the 2016-2017 academic year, broken down by municipality of residence, age, sex, and school. In light of the sample size, the maximum error was estimated to be below $3 \%$ for a confidence level of $95 \%$. In addition, it must be noted that no results with fewer than 25 responses were taken into account when displaying the data.

where

$$
" n "=\frac{N \cdot Z^{2} \cdot p \cdot q}{d^{2}(N-1)+Z^{2} \cdot p \cdot q}
$$

\begin{tabular}{ll}
\hline Error & 0.03 \\
\hline$p$ & 0.50 \\
\hline$q$ & 0.50 \\
\hline$z$ & 1.96 \\
\hline
\end{tabular}

Table 2. Characterization of the secondary school population by sex and age

\begin{tabular}{lllllllllllll}
\hline \multicolumn{1}{l}{ Total in Extremadura } & \multicolumn{10}{c}{ Respondents per age group } & \multirow{2}{*}{ Mean } & \multirow{2}{*}{ SD } \\
\hline Sex & Number & Total & 12 & 13 & 14 & 15 & 16 & 17 & 18 & +18 & & \\
\hline Females & 37,396 & 2305 & 375 & 450 & 323 & 427 & 333 & 273 & 96 & 165 & 14.8 & 2.01 \\
Males & 38,274 & 1889 & 306 & 365 & 353 & 362 & 262 & 199 & 72 & 85 & 14.6 & 1.91 \\
\hline
\end{tabular}

The questionnaire was drawn up based on the information needs defined by the research group and each survey was expected to take around 10 minutes to complete. The paper format questionnaire was tested in December 2016 on respondents chosen at random in two schools in the city of Navalmoral de la Mata (Augustóbriga and Albalat) with the aim of verifying the suitability of the questionnaire, in terms of identifying potential difficulties in understanding the questions, and confirming the average amount of time to schedule for each survey.

The surveys were conducted depending on the number of students present in the classroom during the survey takers' working hours. The aim was that there should always be more than 25 students to complete the survey per grade or at least per school. Likewise, the students must also come from different grade levels.

After all the paper surveys were completed, the results were manually transcribed into the database. The data contained in the Google Drive worksheets were imported from Microsoft Access (used as the database manager) into the table containing the transcribed results. The information was analyzed using descriptive statistical measures.

Ultimately, surveys were taken at a total of 53 schools, taking into account only those that received more than 25 responses per item. The opinion poll was taken on a sampling of students at public and subsidized private schools in the two provinces, taking into account aspects of interest in the study, such as whether the school belonged to the school library network (Red de Bibliotecas Escolares de Extremadura, REBEX), had a bilingual department or immigrant students, or was implementing a reading program. The distribution per province was as follows: 
Table 3. Characteristics of the secondary schools surveyed in the provinces of Badajoz and Cáceres

\begin{tabular}{lccc}
\hline \multirow{2}{*}{ Municipality type } & \multicolumn{3}{c}{ Province of Badajoz / Cáceres } \\
\cline { 2 - 4 } & Schools surveyed & REBEX schools & $\begin{array}{c}\text { Schools with } \\
\text { bilingual department }\end{array}$ \\
\hline$<1,000$ inhab. & $0 / 2$ & $0 / 2$ & $0 / 1$ \\
$1,000-2,000$ inhab. & $1 / 1$ & $1 / 2$ & $0 / 0$ \\
$2,000-5,000$ inhab. & $6 / 7$ & $4 / 4$ & $3 / 1$ \\
$5,000-10,000$ inhab. & $6 / 8$ & $4 / 4$ & $2 / 5$ \\
$10,000-20,000$ inhab. & $3 / 2$ & $1 / 2$ & $1 / 2$ \\
$>20,000$ inhab. & $10 / 7$ & $6 / 4$ & $9 / 6$ \\
\hline
\end{tabular}

Table 4. Students in Badajoz and Cáceres broken down by sex

\begin{tabular}{lcc|cc}
\hline \multirow{2}{*}{ Municipality type } & \multicolumn{2}{c|}{ Province of Badajoz } & \multicolumn{2}{c}{ Province of Cáceres } \\
\cline { 2 - 5 } & $\begin{array}{c}\text { Females } \\
\text { surveyed }\end{array}$ & $\begin{array}{c}\text { Males } \\
\text { surveyed }\end{array}$ & $\begin{array}{c}\text { Females } \\
\text { surveyed }\end{array}$ & $\begin{array}{c}\text { Males } \\
\text { surveyed }\end{array}$ \\
\hline$<1,000$ inhab. & 68 & 51 & 155 & 136 \\
1,000/2,000 inhab. & 65 & 57 & 169 & 135 \\
2,000/5,000 inhab. & 333 & 300 & 157 & 109 \\
5,000/10,000 inhab. & 318 & 270 & 214 & 154 \\
$10,000 / 20,000$ inhab. & 147 & 146 & 171 & 147 \\
$>20,000$ inhab. & 489 & 361 & 200 & 186 \\
\hline
\end{tabular}

A database was generated to process the surveys efficiently and effectively. Three entities were described in the database: students, municipalities, and zones. After defining the tables accordingly, queries were created using the SQL query language (the specific language that gives access to a relational database management system to specify different types of operations), and the database was implemented in Microsoft Access.

When the query process was completed and saved in the database, the desired outcome was to display data in relation to the geographical component - that is, produce a thematic map. To achieve this, a connection was needed between Microsoft Access, where the alphanumerical database was managed, and ArcGIS 10.2, the geographic information system in which the graphical outputs would be created.

\section{Results}

\subsection{Mapping}

The secondary school students with the lowest reading rates are concentrated in the districts along the border with Portugal and in the north of the region (Figure 2) and partly mirror the map of students at the same educational stage who make the fewest book purchases (Figure 3). Along the same lines, purchases of books are associated with urban areas in the region, perhaps as a result of greater purchasing power and the broader range of books offered in towns and cities in comparison to rural settings. 
Figure 2. Percentage of students that read 0 or 1 book per month in secondary school

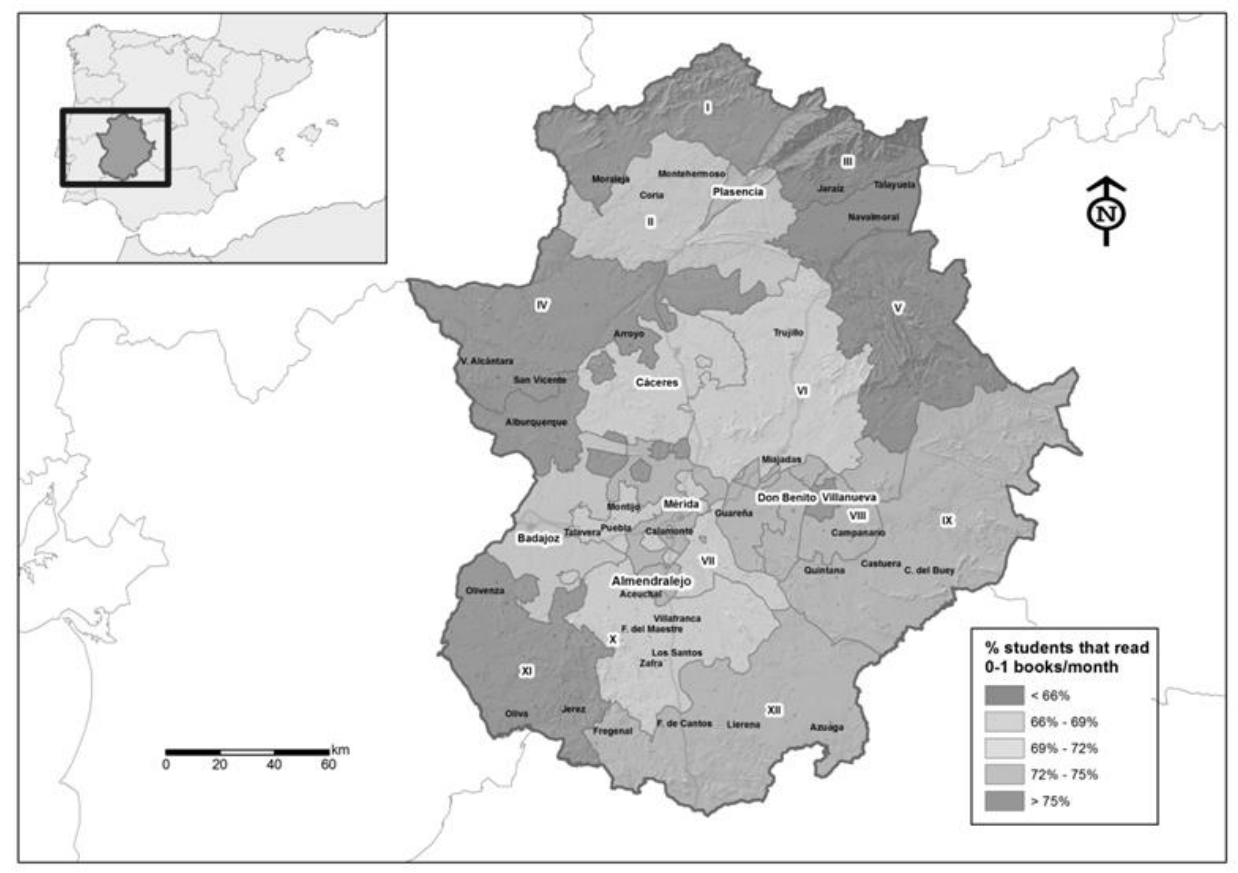

Figure 3. Percentage of students that purchase 0 or 1 book per year in secondary school

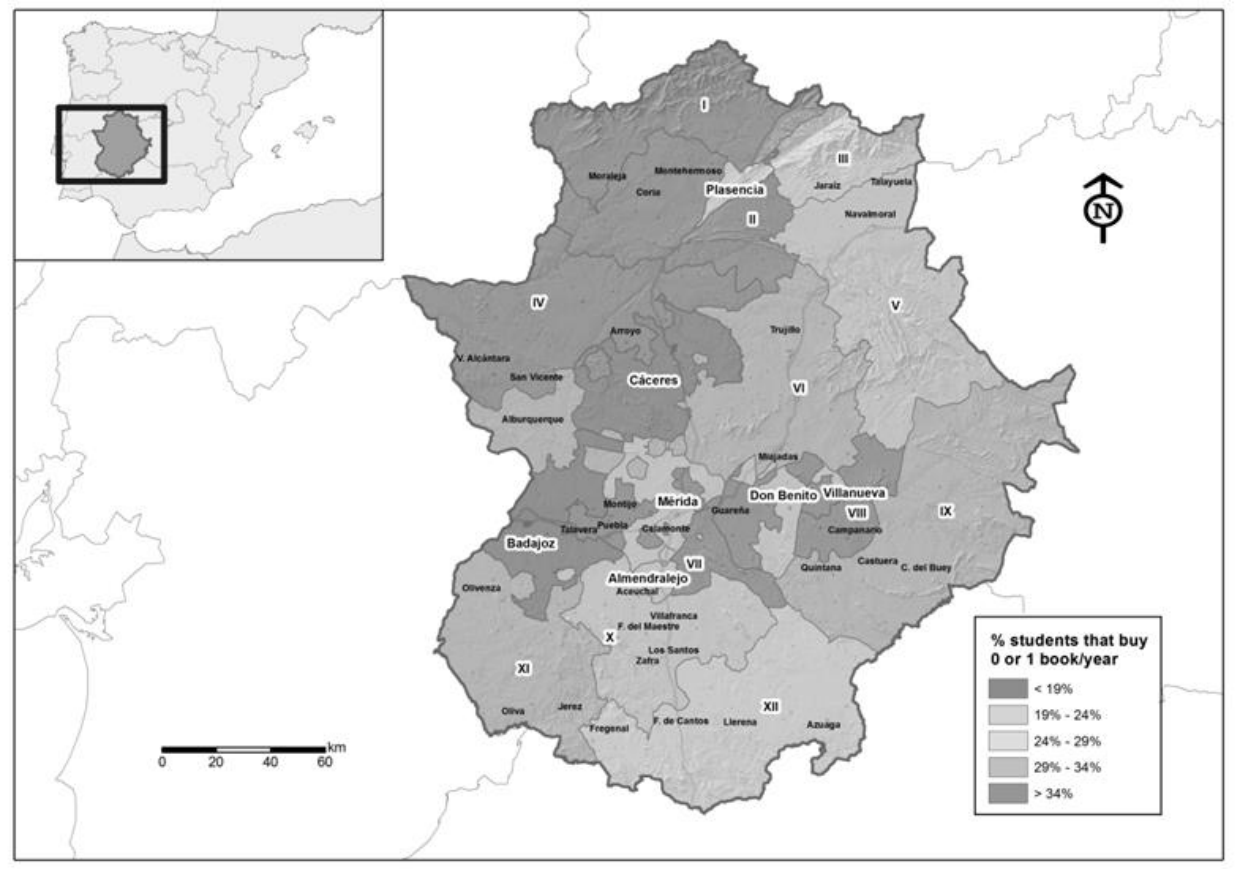

This is undoubtedly one of the most concerning findings, since $70 \%$ of the students in 7 out of the 19 zones studied admit not spending more than two hours per week reading. In all three aspects analyzed thus far, zone I was found to have the lowest results for each item (Figure 4). 
Figure 4. Percentage of secondary school students that read fewer than two hours per week

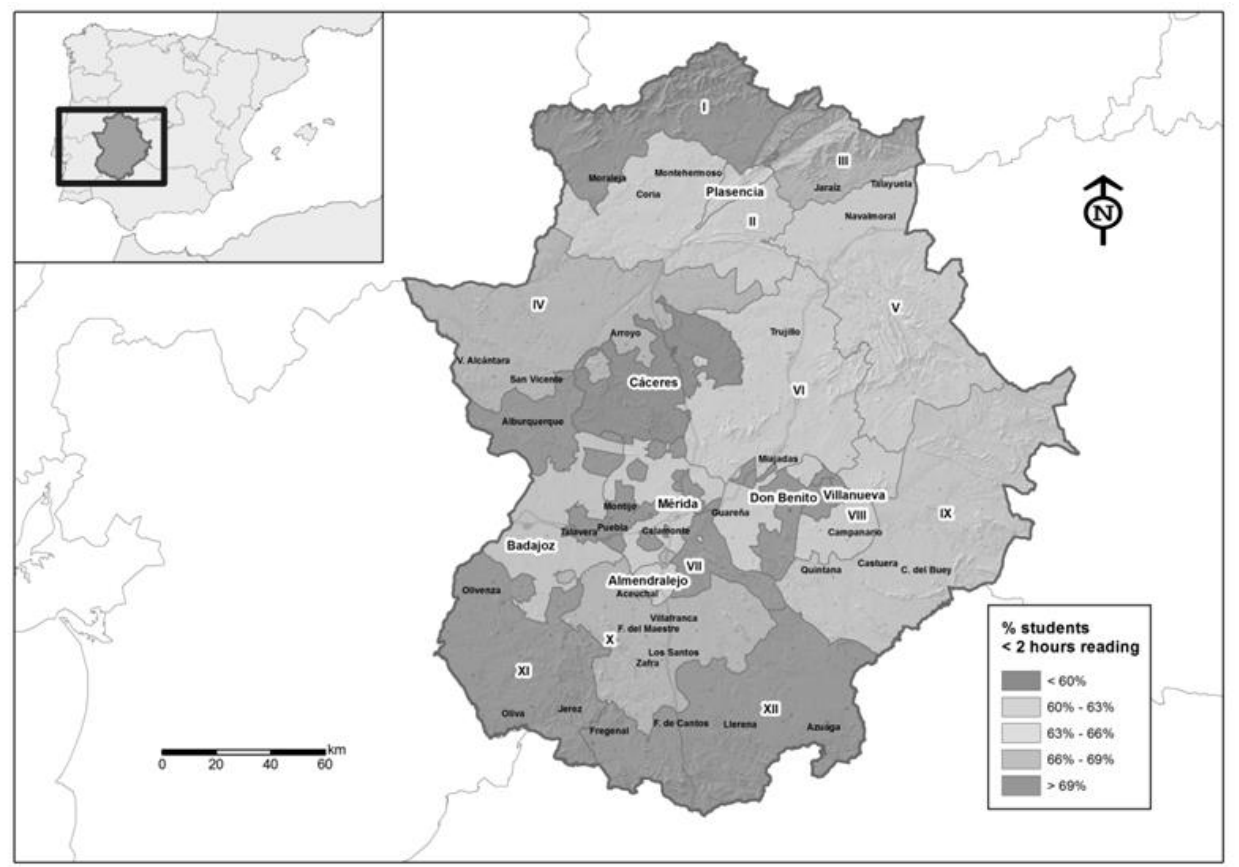

As illustrated in Figure 5, a nearly 20\% higher rate of reading in other languages was observed in the province of Cáceres compared to Badajoz, where the city of Almendralejo is particularly noteworthy. Once again, the areas along the Portuguese border in Badajoz scored the lowest in this regard.

Figure 5. Percentage of secondary school students that do not read in any other language

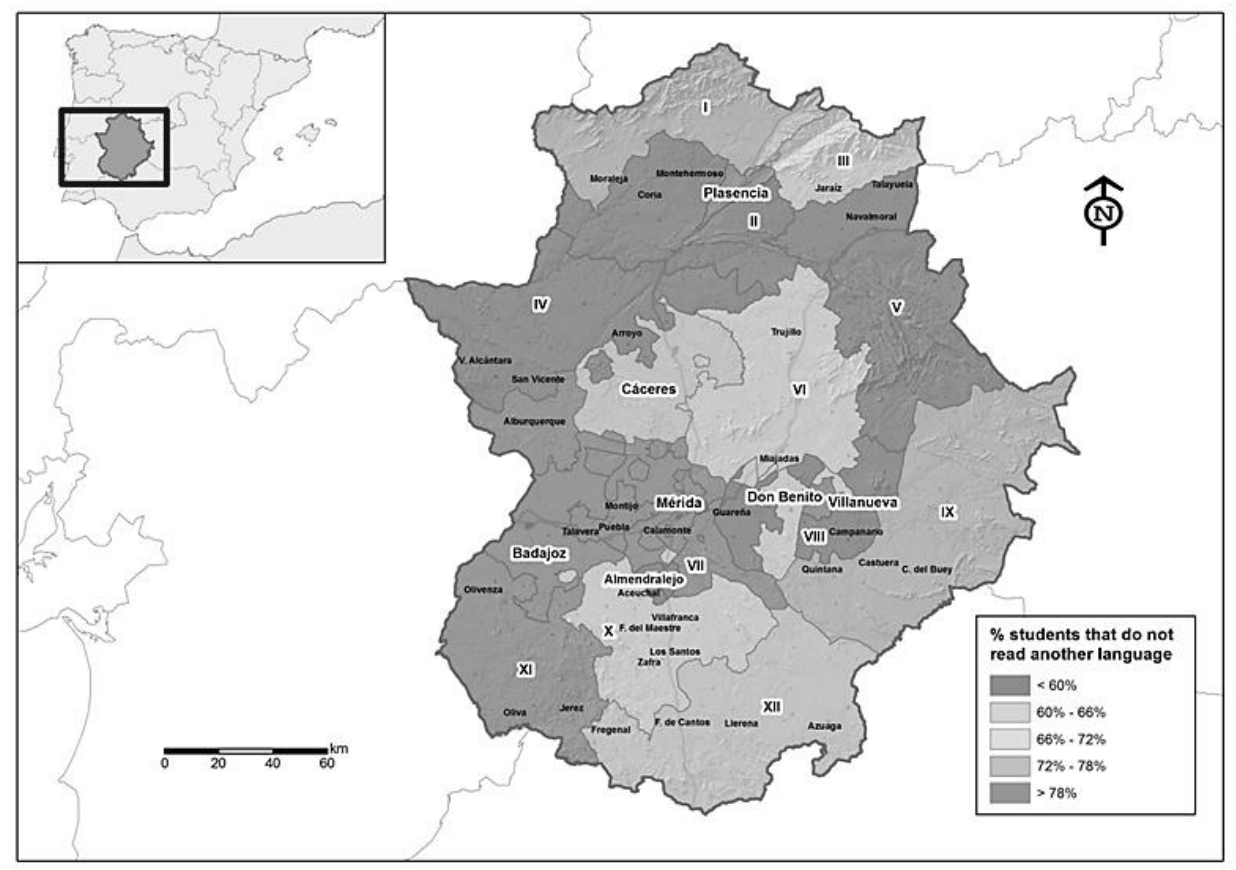


Figure 6 shows that differences in the use of social networks are minimal throughout the region, with just 5 percentage points between the extremes. This means that social networks are widely used in both urban and rural areas, albeit notably less so in the cities of Extremadura.

Figure 6. Percentage of secondary school students that use social networks

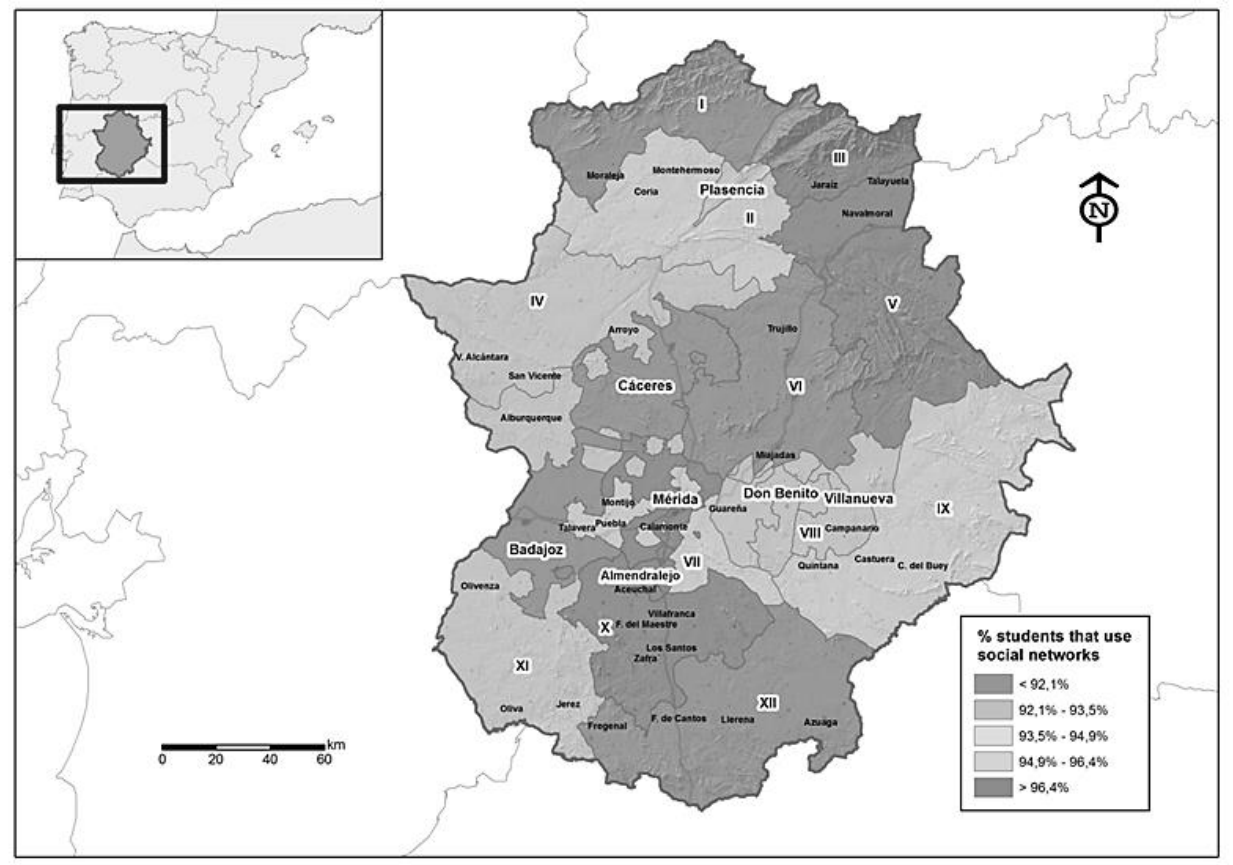

The results of the variables analyzed are presented in charts firstly in terms of respondents' sex and age, and secondly, based on whether the schools participate in certain educational programs such as the school library network REBEX or have bilingual departments (English-Spanish) or specific reading programs.

\subsection{Results broken down by sex, age and educational stage of the respondents}

From Figure 7, which reports the number of books read per month, it should be noted that $15 \%$ more men than women read no books. As age increases, reading declines, with the percentage of non-readers jumping from less than $10 \%$ at the age of 12 to nearly $50 \%$ at the age of 20 . This proves that these years are essential in understanding the drop in reading habits among the people of Extremadura. 
Figure 7. Number of books read per month by secondary school students, by sex and age
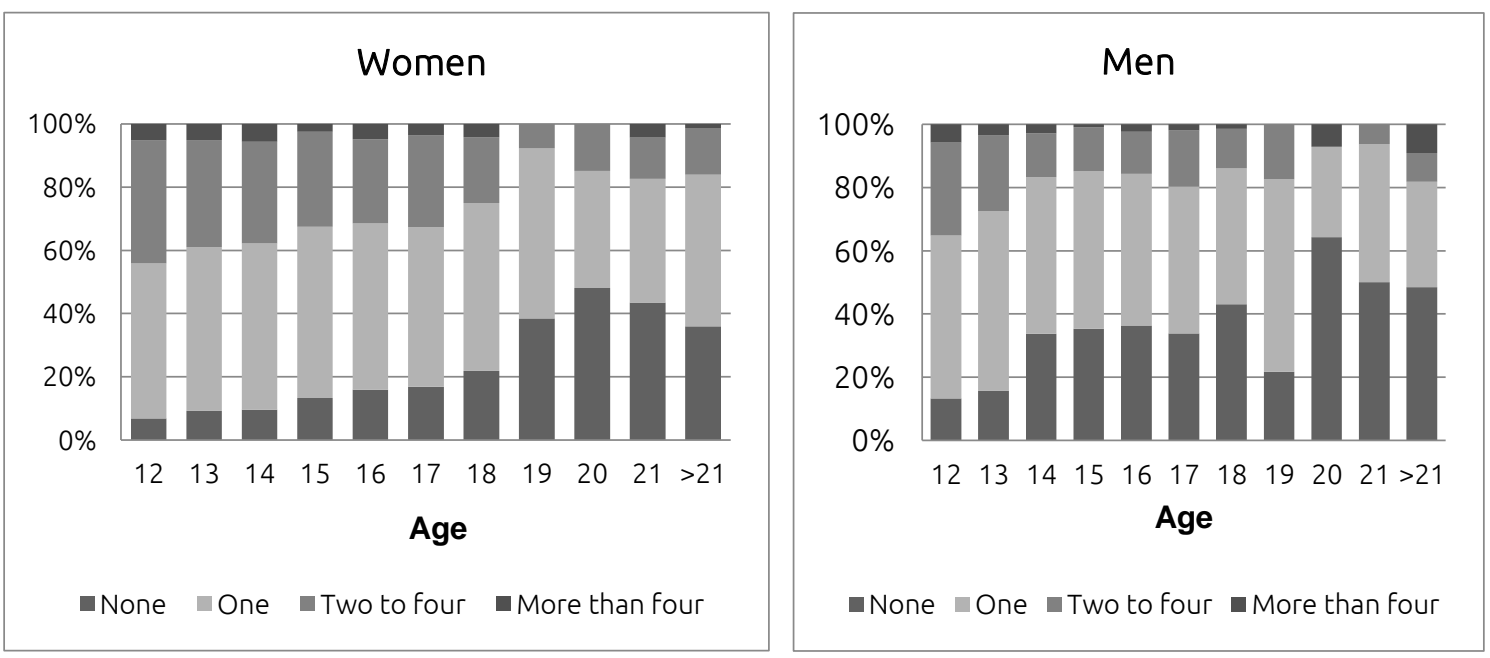

This trend is even more marked among students that attend vocational training courses, in which the percentage of non-readers is double the figure for compulsory secondary education (ESO) and Baccalaureate students of both sexes. Figure 8 illustrates this:

Figure 8. Number of books read per month by secondary school students, by type of studies chosen

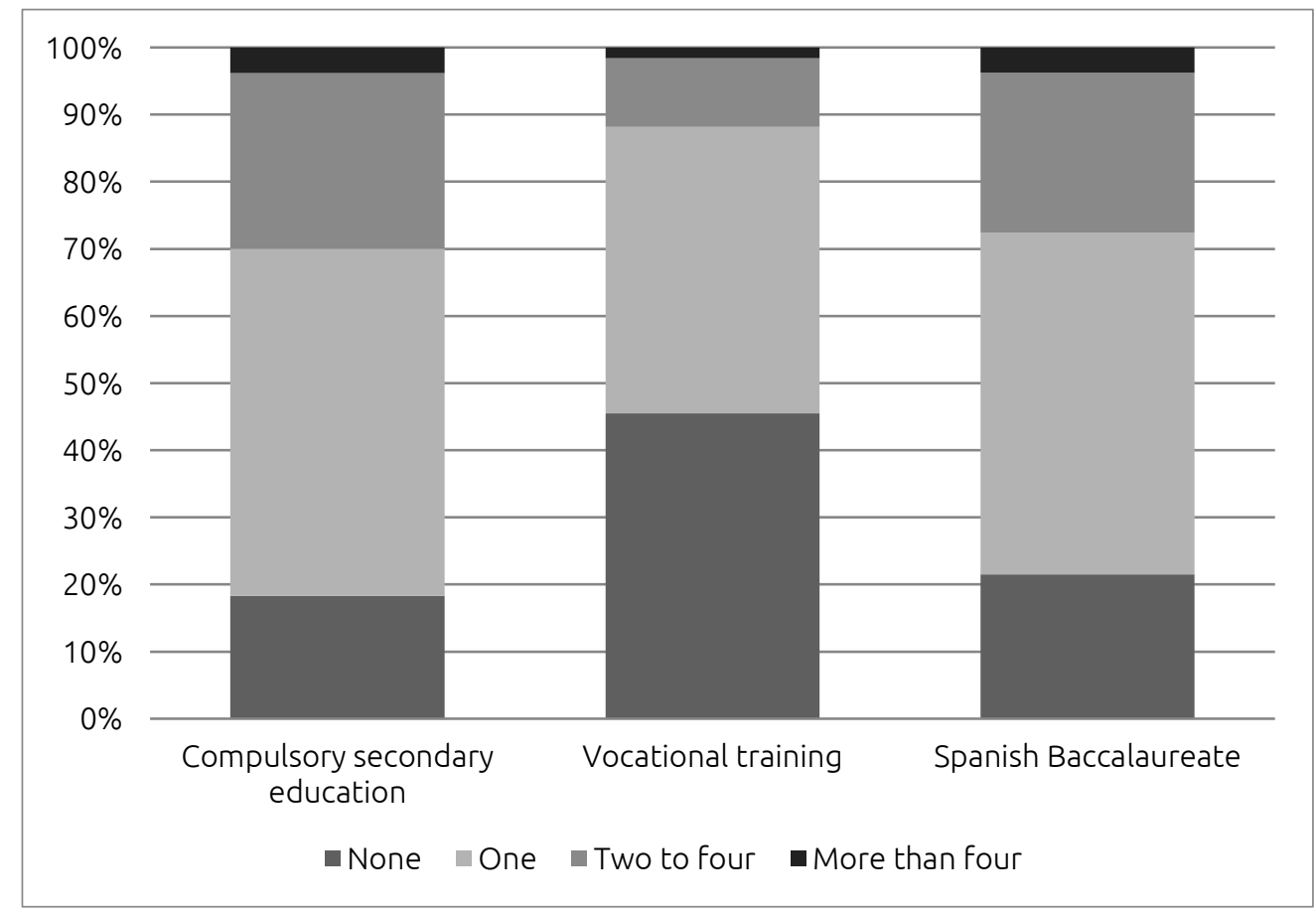

The same trend is seen in library visits by adolescents in Extremadura, although there is little difference by sex, except among those aged 19 and 20, when the trend for men improves while women report visiting libraries to a lesser degree. The frequency of library visits gradually declines from the age of 12 onwards. While in general quite a high percentage of students never visit a library, this figure is higher among men than women. Students in compulsory secondary education and the Baccalaureate visit the library more often than those in vocational training courses, as shown in Figure 9. 
Figure 9. Visits to the library by secondary school students, by sex and age
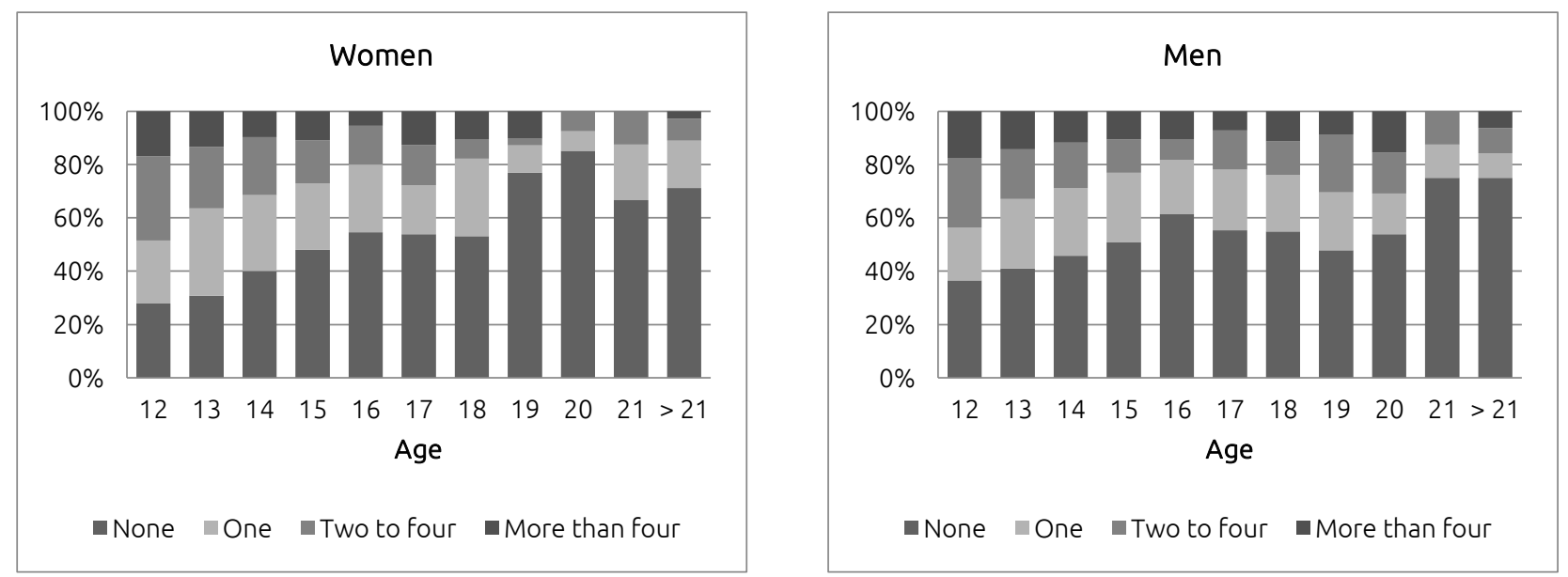

Meanwhile, the percentage of respondents that do not buy any books per year is $9 \%$ higher among men than women. Women purchase on average 4.51 books per year while men buy 3.49, which helps explain the fact that reading habits are more prevalent among the female population. This can be seen in Figure 10:

Figure 10. Number of books purchased per year by secondary school students, by sex and age
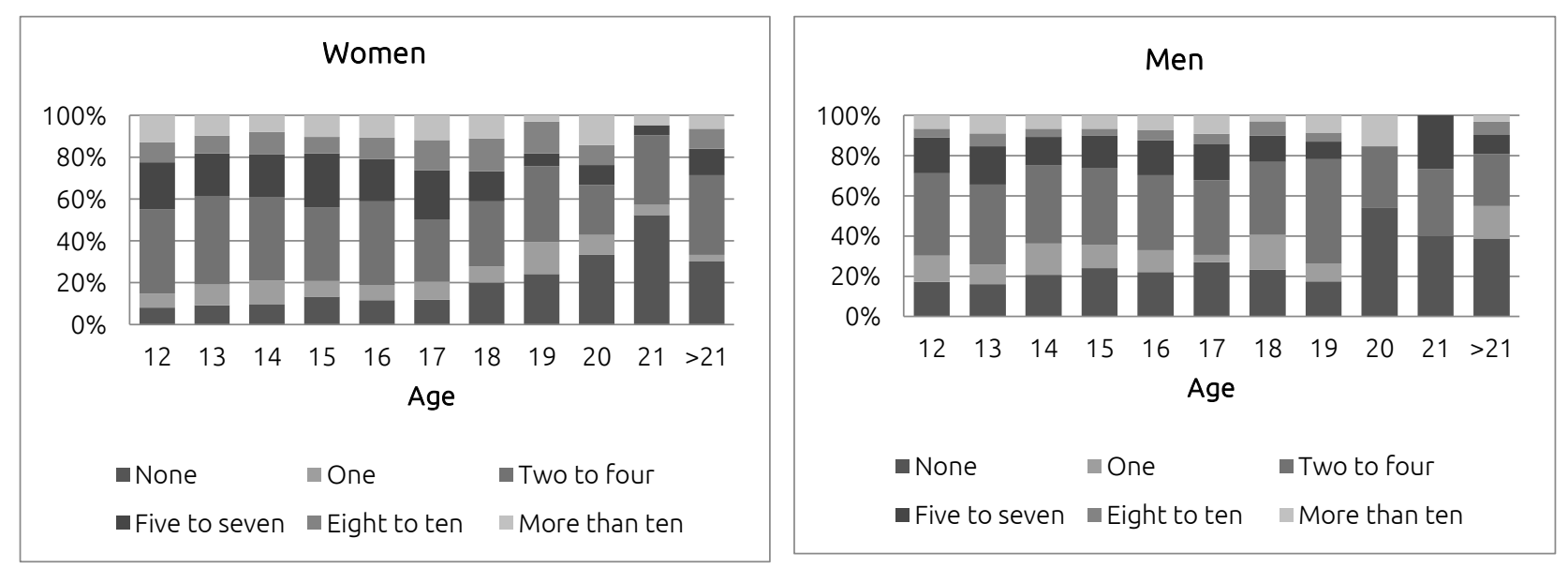

While a majority of women claim to enjoy reading, almost half of men say they read because they feel obligated to, particularly in the 14 to 18-year-old age range. This subjective perception of reading is a highly reliable indicator that shapes all results. This can be seen in Figure 11: 
Figure 11. Reason for reading, by sex and age
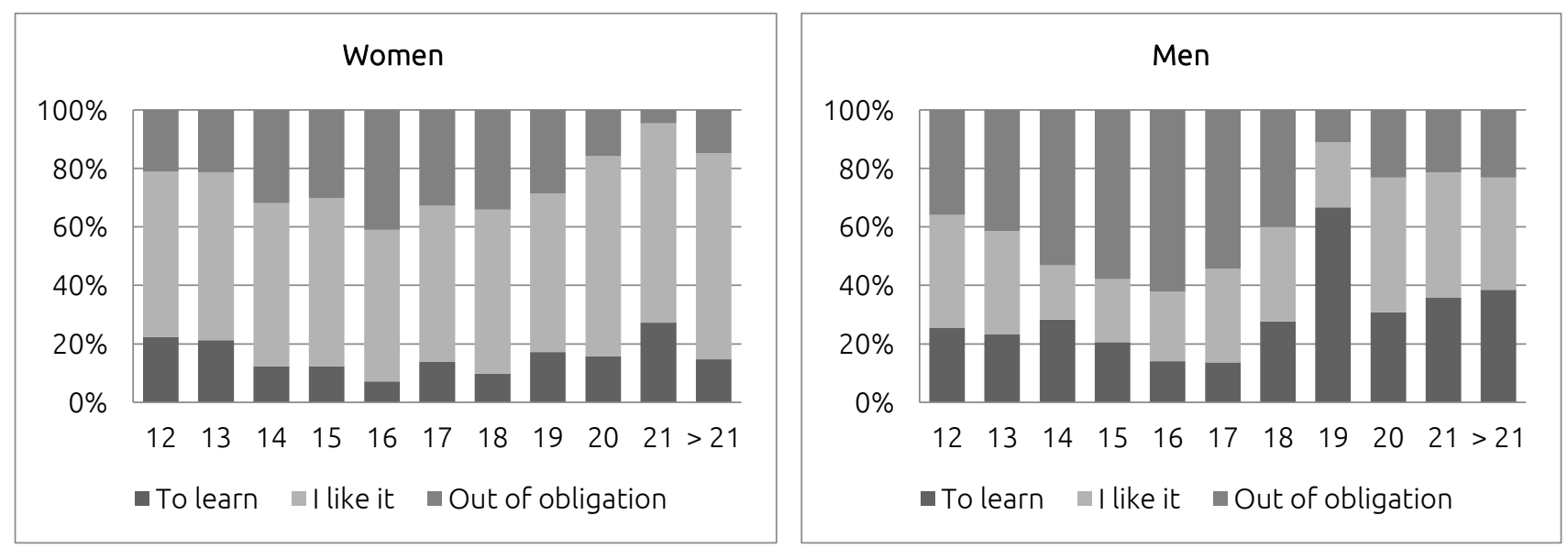

According to Figure 12, although a majority of students only read in Spanish, the percentage of students who do read in another language is $10 \%$ higher among women than among men, on average. By educational stage, $33 \%$ of compulsory secondary education students, $25 \%$ of those in the Baccalaureate, and $8 \%$ of respondents taking vocational training courses read in another language.

Figure 12. Reading in a language other than Spanish, by sex and age
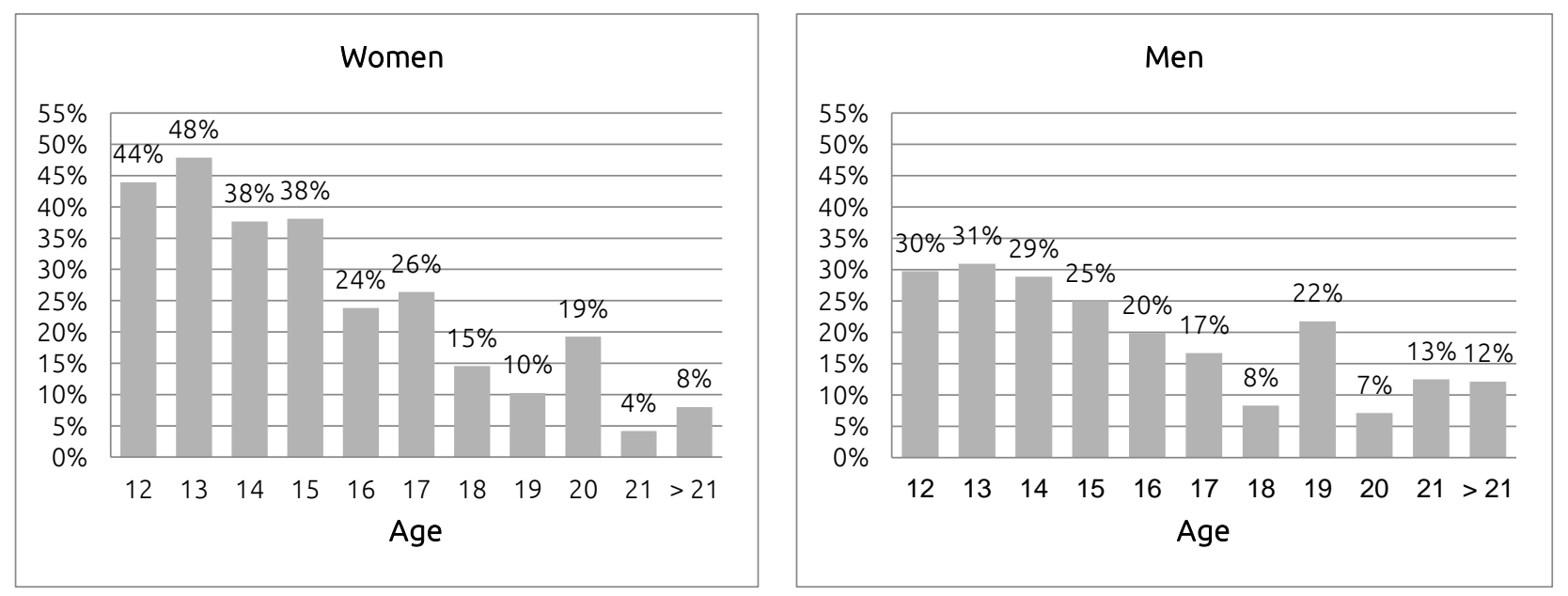

As illustrated in Figure 13, more than half of women claim to read in their free time, while for men this figure is $41 \%$. All across the board, a change in behavior can be noted among 19-year-old men, compared to women of the same age and even men from other age ranges. For the most part, these 19-year-old men are students who had to repeat a year of school and are maturing, and hope to finish their high school studies and secure a place at university. 
Figure 13. Reading in free time, by sex and age
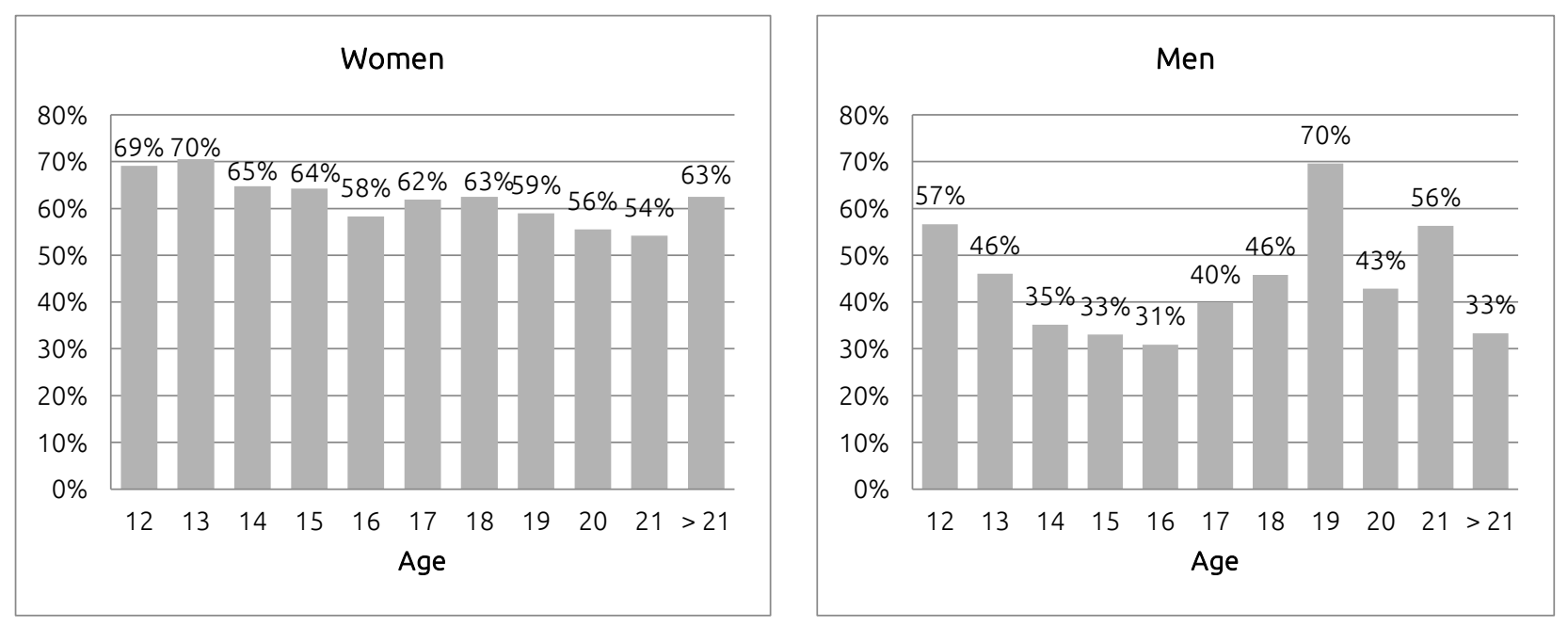

\subsection{Results according to the characteristics of the school attended: REBEX, bilingual departments, and reading programs}

Figure 14 shows that the fact that a school is part of the School Library Network of Extremadura (REBEX) has no considerable influence on the frequency with which students visit the library: the same percentages are seen for those who never go and those who go once a month. However, schools that are part of REBEX have $3 \%$ more students who visit the library more than four times a week. Even so, it must be emphasized that the differences are by no means significant. These data should give educational authorities pause for thought: it may be that much of the funding and effort is being expended on managing and computerizing the libraries instead of encouraging reading.

Figure 14. Library visits per month, based on participation in REBEX
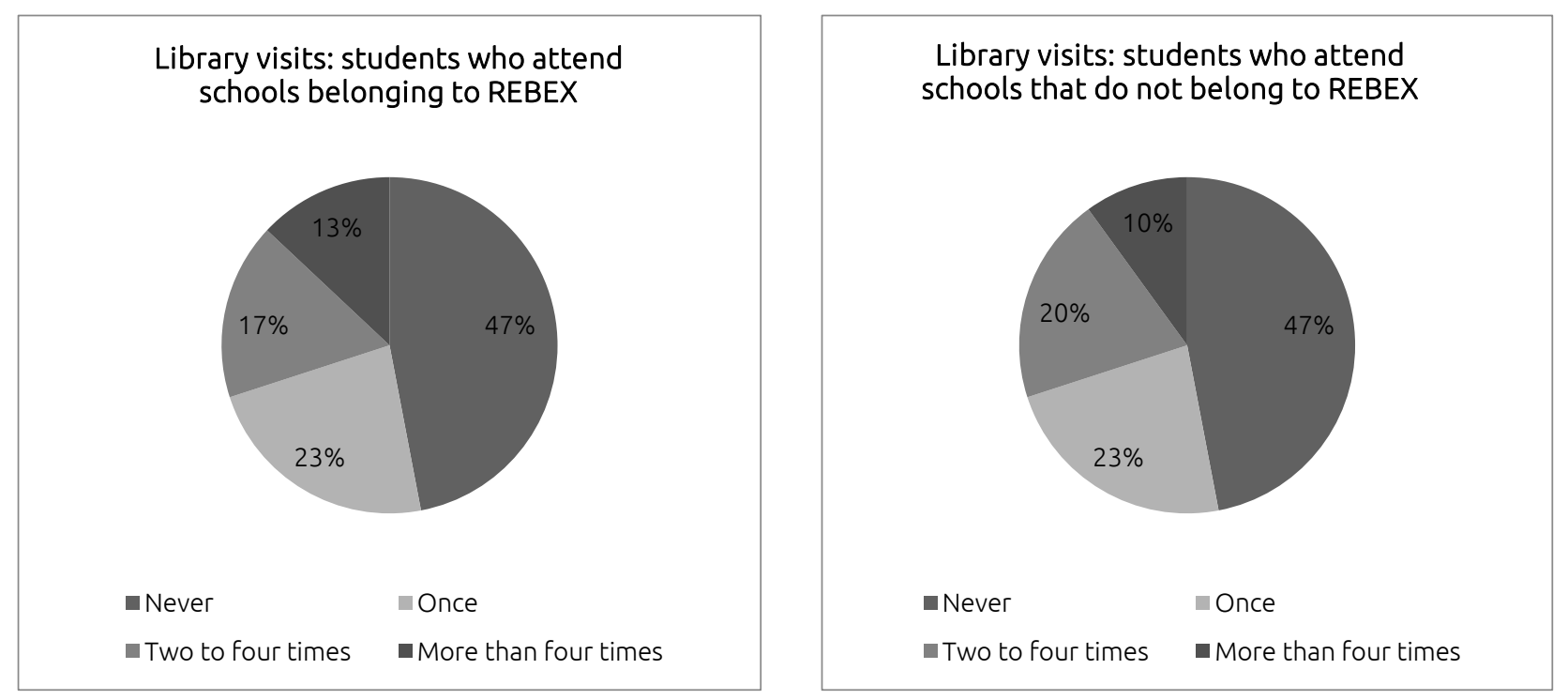
To conclude, the analysis of the number of books read by students in schools with or without a reading program reveals no great difference in favor of schools with reading programs. Indeed, paradoxically, Figure 15 shows that there are $4 \%$ more students who do not read any books in a month at schools with a reading program.

Figure 15. Books read per month, based on whether a reading program is in place at the school
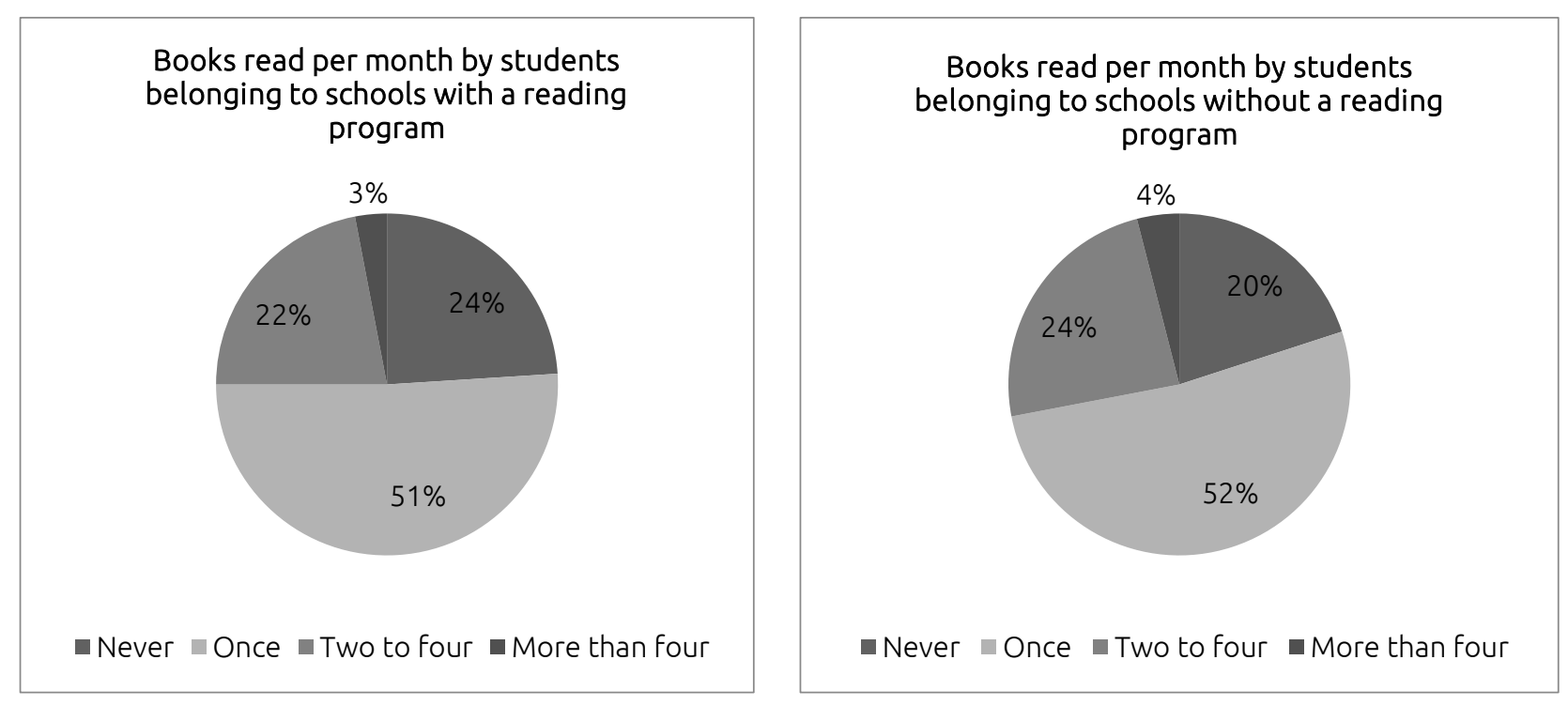

\section{Discussion}

The research described in the manuscript used a self-report instrument to examine the reading habits of secondary school students. The analysis of descriptive statistics employed in this research has been endorsed by other studies describing the same variables (Pérez-Parejo et al., 2018a; Pérez-Parejo et al., 2018b).

Our research took into account two aspects that are of particular relevance and interest in the literature consulted: disaggregation of results by sex (Logan \& Johnston, 2009; McGeown et al., 2012) and the question of motivation for reading (Pitcher et al., 2007). In particular, this last aspect determines to a large extent the results obtained.

In this respect, our results are consistent with those of surveys from other parts of the world. For example, Fuentes et al. (2019) showed that in primary education in Chile, reading attitudes have proven to be relevant in reading performance (p. 225), which is in line with our results for secondary education in Extremadura. In conclusion, this subjective perception of reading is a highly reliable indicator that shapes the full set of results.

The differentiation by sex exhibits similarities with the results of previous studies in Finland and Estonia, with a lower reading index in boys and spaces with demographic characteristics similar to those of our study area (peripheral territories and a dispersed population), although their model of education and PISA results are very different (Säälik, 2015). We are aware that it would be desirable to analyze the socioeconomic variables of the studied population (per capita income) as this is a factor that has been taken into account in other studies (Yusof, 2010), and perform a national comparison with other regions that share the same educational model, and these are limitations of our work. Based on the interesting conclusions reached by other similar studies, our future work should cover, as a new line of research, other variables that allow us to make a deeper comparison with recent studies that point to the relevance of reading profiles and models (Errázuriz et al., 2019) and teachers' own conceptions about reading (Errázuriz et al., 2020), variables that, as these studies show, condition the results of any survey on this topic. Likewise, it was found that teachers with an epistemic profile derive greater pleasure from reading and tend to teach subjects associated with language, while those 
with a more reproductive profile report reading for practical reasons (Errázuriz et al., 2019, p. 420).

On the other hand, we believe that a line of research has been opened by the geographical positioning of respondents and the generation of a thematic map of results, which makes it possible to visualize the impact of road and rail infrastructure on reading habits and literacy processes in rural contexts like the one studied.

The paper has great potential and we believe it could make an important contribution to the wider body of research. Reading habits are an important factor in literacy development and may therefore be of interest to readers. Novel aspects of this study include its focus on a minority population and the use of a large, stratified, randomly-sampled population.

\section{Conclusions}

The hypotheses or research issues taken as the central theme, which were presented in the introduction to this study and also served as a framework for presenting and analyzing the results, were used in drafting these conclusions.

First of all, the results shown in the maps indicate that the differences between geographic areas within the autonomous community were less conspicuous than expected, revealing progressive educational equity. Even so, the provincial capitals, largest towns, and best connected areas always achieved somewhat better results whereas the lowest scores were observed, with a few exceptions, in zones with the highest levels of rurality, specifically in the districts in northern Cáceres and along the border with Portugal. In this sense, a response is needed from the region's educational authorities in order to achieve full equality.

It is worth noting that $21 \%$ of respondents ( $14 \%$ of women and $29 \%$ of men) report not reading any books in a month, although this figure is variable based on the determining factors examined in this paper. Similarly, $67 \%$ of students devote less than two hours per week to reading, which is a very low rate with a wide margin for improvement. The general trend is that reading rates decrease as age increases. In addition, students in vocational training read less than those in compulsory secondary education (ESO) or upper secondary school (Baccalaureate).

The differences in reading habits by sex confirm that women read at higher rates than men across all the age groups analyzed, with women reading an average of 1.6 books a month, compared to 1.18 for men. Despite the fact that $54 \%$ of students do not read in their free time (35\% of women and $59 \%$ of men), the trend whereby girls read more than boys still applies. This trend is further echoed in spending on books (16\% of women and $25 \%$ of men do not buy books), library visits and the subjective perception of reading as a leisure activity.

In terms of the variables related to school participation in special educational programs, the reading rate at bilingual schools is 5 percentage points higher, which is perhaps a smaller difference than might be expected. Whether or not the school belongs to the school library network REBEX does not have a marked impact on the statistics. The data do not vary depending on whether or not the schools participate in reading programs either, which should give the authorities cause for reflection when reviewing these educational programs.

Paper books are the preferred and most common reading format for all ages and educational stages, followed by mobile phones and tablets, which are preferred over computers. The vast majority of students report using mobile phones as a means of accessing social networks in both urban and rural settings. In this regard, mobile use is no lower in rural than in urban settings.

To conclude, it is important to note other data obtained that may affect reading habits. Nearly half of secondary school students (46\%) admit that they never visit the library, $44 \%$ for women and $49 \%$ for men, and two in ten secondary school students do not purchase any books per yеar. The preferred genres are, in descending order, fictional works and textbooks. In addition, 35\% of students admit that they read mainly because they are required to, so they do not consider this a common leisure activity outside the classroom. This subjective perception is always a highly reliable indicator that shapes all results on reading habits across 
different age groups and educational stages.

\section{Referencias}

Applegate, A. J., \& Applegate, M. D. (2004). The Peter effect: Reading habits and attitudes of preservice teachers. The Reading Teacher, 57, 554-563.

Asselin, M. (2000). Confronting assumptions: Preservice teachers' beliefs about reading and literature. Reading Psychology, 21(1), 31-55. https://doi.org/10.1080/027027100278338

Benevides, T., \& Peterson, S. S. (2010). Literacy attitudes, habits and achievements of future teachers. Journal of Education for Teaching, 36(3), 291-302. https://doi.org/10.1080/02607476.2010.497375

Brasseur-Hock, I. F., Hock, M. F., Kieffer, M. J., Biancarosa, G., \& Deshler, D. D. (2011). Adolescent struggling readers in urban schools: Results of a latent class analysis. Learning and Individual Differences, 21(4), 438-452. https://doi.org/10.1016/j.lindif.2011.01.008

Coiro, J., \& Dobler, E. (2007). Exploring the online reading comprehension strategies used by sixth-grade skilled readers to search for and locate information on the Internet. Reading Research Quarterly, 42(2), 214257. https://doi.org/10.1598/RRQ.42.2.2

Corpas, M. D. (2014). Análisis y evaluación de la comprensión lectora en inglés como lengua extranjera en Educación Secundaria Obligatoria [Analysis and evaluation of reading comprehension in English as a foreign language in compulsory secundary education (ESO)]. Philologica Urcitana, 11, 1-16. https://core.ac.uk/download/pdf/143455061.pdf

Cremin, T., Mottram, M., Collins, F., Powell, S., \& Safford, K. (2009). Teachers as readers: Building communities of readers. Literacy, 43(1), 11-19. https://doi.org/10.1111/i.1741-4369.2009.00515.x

Cunningham, A. E., \& Stanovich, K. E. (1998). What reading does for the mind. American Educator, 22(1-2), 817. https://mccleskeyms.typepad.com/files/what-reading-does-for-the-mind.pdf

Daisey, P. (2009). The reading experiences and beliefs of secondary pre-service teachers. Reading Horizons, 49(2), 167-190.

https://scholarworks.wmich.edu/cgi/viewcontent.cgi?article=1053\&context=reading horizons

Dobson, A., Pérez, M. D., \& Johnstone, R. (2010). Programa de educación bilingüe en España. Informe de evaluación [Bilingual education program in Spain. Evaluation report]. Ministerio de Educación; British Council. https://www.britishcouncil.es/sites/default/files/british-council-programa-educacion-bilingue-esp-informeevaluacion.pdf

Duncan, L.G., Mcgeown, S.P., Griffiths, Y.M., Stothard, S.E., \& Dobai, A. (2016). Adolescent reading skill and engagement with digital and traditional literacies as predictors of reading comprehension. British Journal of Psychology, 107(2), 209-238. https://doi.org/10.1111/bjop.12134

Eason, S. H., Goldberg, L. F., Young, K. M., Geist, M. C., \& Cutting, L. E. (2012). Reader-text interactions: How differential text and question types influence cognitive skills needed for reading comprehension. Journal of Educational Psychology, 104(3), 515-528. https://doi.org/10.1037/a0027182

Errázuriz, M. C., Becerra, R., Aguilar, P., Cocio, A., Davison, O., \& Fuentes, L. (2019). Perfiles lectores de profesores de escuelas públicas de la Araucanía, Chile: Una construcción de sus concepciones sobre la lectura [Reading profiles of teachers in public schools in Araucanía, Chile: A construction of their conceptions about reading]. Perfiles Educativos, 41(164), 28-46.

https://doi.org/10.22201/iisue.24486167e.2019.164.58856 
Errázuriz, M. C., Fuentes, L., Davison, O., Cocio, A., Becerra, R., \& Aguilar, P. (2020). Concepciones sobre la lectura del profesorado de escuelas públicas de la Araucanía: ¿Cómo son sus perfiles lectores? [Public school teachers' conceptions about reading in Araucanía: What are their reading profiles like?]. Revista Signos, 53(103), 419-448. http://www.revistasignos.cl/index.php/signos/article/view/219

Fuentes, L., Errázuriz, M. C., Davison, O., \& Cocio, A. (2019). Validación de una encuesta de actitudes de lectura en estudiantes de educación básica [Validation of a survey on reading attitudes in students of basic level education]. Literatura y Lingüística, 39, 225-250.

https://scielo.conicyt.cl/pdf/lyl/n39/0716-5811-lyl-39-00225.pdf

Fundación Germán Sánchez Ruipérez. (2008). Hábitos de lectura y compra de libros en Extremadura [Reading and book purchasing habits in Castile-La Mancha]. Plan de Fomento de la Lectura en Extremadura.

Fundación Germán Sánchez Ruipérez. (2009). Hábitos de lectura y compra de libros en Castilla-La Mancha (14 a 24 años) [Reading and book purchasing habits in Extremadura (14 to 24-year-olds)]. Plan de Fomento de la Lectura en Extremadura.

Gil, J. (2009). Hábitos y actitudes de las familias hacia la lectura y competencias básicas del alumnado [Family habits and attitudes towards reading and students' basic competences]. Revista de Educación, 350, 301-322. http://www.revistaeducacion.educacion.es/re350/re350 13.pdf

Granado, C. (2014). Teachers as readers: A study of the reading habits of future teachers / El docente como lector: Estudio de los hábitos lectores de futuros docentes. Cultura y Educación, 26(1), 44-70.

https://doi.org/10.1080/11356405.2014.908666

Grecu, M., Titan, E., \& Druica, E. (2015). Investigating the costs of education in the European Union. Procedia. Economics and Finance, 23, 808-817. https://doi.org/10.1016/S2212-5671(15)00592-4

Jiménez, J. E., Rodríguez, C., Suárez, N., O’Shanahan, I., Villadiego, Y., Uribe, C., Villalobos, J. A., \& Rodas, P. (2015). Teachers' implicit theories of learning to read: A cross-cultural study in Ibero-American countries. Reading and Writing, 28(9), 1355-1379. https://doi.org/10.1007/s11145-015-9574-z

Logan, S., \& Johnston, R. (2009). Gender differences in reading ability and attitudes: Examining where these differences lie. Journal of Research in Reading, 32(2), 199-214.

https://doi.org/10.1111/j.14679817.2008.01389.x

Mate, M., \& Harris, R. (2013). Differential empirical innovation factors for Spain and the UK. Research Policy, 43(2), 451-463. https://doi.org/10.1016/i.respol.2013.10.013

McGeown, S. P., Goodwin, H., Henderson, N., \& Wright, P. (2012). Gender differences in reading motivation: Does sex or gender identity provide a better account? Journal of Research in Reading, 35(3), 328336. https://doi.org/10.1111/j.1467-9817.2010.01481.x

Moret, Z. (1999). Dejad que los libros vengan a mí, o la aventura de leer y escribir creativamente [Let books come to me, or the adventure of reading and writing creatively]. In Fundación Germán Sánchez Ruipérez (Ed.), Animar a escribir para animar a leer (pp. 179-190). Fundación Germán Sánchez Ruipérez.

Muñoz, J. M., \& Hernández, A. (2011). Hábitos lectores de los alumnos de la ESO en la provincia de Salamanca. ¿Son el género y el entorno factores diferenciales? [Reading habits of students of compulsory secondary education (ESO) in the province of Salamanca: Are gender and environment differential factors?]. Revista de Educación, 354, 605-628.

http://www.educacionyfp.gob.es/dam/icr:ea53dd08-a63c-4c8f-9691-0210c037e378/re35424-pdf.pdf 
Nieto, A., \& Cárdenas, G. (2015). El Método LEADER como política de desarrollo rural en Extremadura en los últimos 20 años (1991-2013) [The LEADER method as a rural development policy in Extremadura in the last 20 years (1991-2013)]. Boletín de la Asociación de Geógrafos Españoles, 69, 139-162.

http://dx.doi.org/10.21138/bage.1893

OECD (2018). PISA 2015. Results in Focus. https://www.oecd.org/pisa/pisa-2015-results-in-focus.pdf

Olaziregi, M. J. (2000). Aproximación sociológica a los hábitos de lectura de la juventud vasca [Sociological approach to the reading habits of Basque youth]. BIBLID, 18, 79-93.

https://core.ac.uk/download/pdf/11495951.pdf

Orellana, P., Melo, C., Baldwin, P., De Julio, S., \& Pezoa, J. (2020). The relationship between motivation to read and reading comprehension in Chilean elementary students. Reading and writing.

https://doi.org/10.1007/s11145-020-10051-3

Pérez-Parejo, R., Gutiérrez-Cabezas, A., Soto-Vázquez, J., Jaraíz-Cabanillas, F. J., \& Gutiérrez-Gallego, J. A. (2018a). Hábitos de lectura en lenguas extranjeras en los estudiantes de Extremadura [Foreign language reading habits in students of Extremadura]. Ocnos, 17(2), 67-81.

https://doi.org/10.18239/ocnos 2018.17.2.1714

Pérez-Parejo, R., Gutiérrez-Cabezas, A., Soto-Vázquez, J., Jaraíz-Cabanillas, F. J., \& Gutiérrez-Gallego, J. A. (2018b). Géneros de lectura preferidos por los alumnos extremeños. Datos y análisis [Preferred reading genres of students from Extremadura. Data and analysis]. Información, cultura y sociedad, 39, 71-92. https://doi.org/10.34096/ics.i39.4208

Petscher, Y. (2010). A meta-analysis of the relationship between student attitudes towards reading and achievement in reading. Journal of Research in Reading, 33(4), 335-355. https://doi.org/10.1111/j.1467$\underline{9817.2009 .01418 . x}$

Pitcher, S. M., Albright, L. K., DeLaney, C. J., Walker, N. T., Seunarinesingh, K., Mogge, S., Headley, K. N., Gentry, V., Peck, S., Hunt, R. y Dunston, P. J. (2007). Assessing adolescents' motivation to read. Journal of Adolescent and Adult Literacy, 50(5), 378-396. https://doi.org/10.1598/JAAL.50.5.5

Poulain, M. [Ed.] (1988). Pour une sociologie de la lecture [For a sociology of reading]. Éditions du Cercle de la Librairie.

Säälik, Ü. (2015). Learning strategies explaining boys' and girls' reading performance in schools with different language. Procedia - Social and Behavioral Sciences, 180, 1649-1655.

https://doi.org/10.1016/i.sbspro.2015.05.059

Serna, M., Rodríguez, A., \& Etxaniz, X. (2017). Biblioteca escolar y hábitos lectores en los escolares de Educación Primaria [School libraries and reading habits in children in elementary education]. Ocnos, 16(1), 1849. http://dx.doi. org/10.18239/ocnos 2017.16.1.1205

Schaffner, E., Schiefele, U., \& Ulferts, H. (2013). Reading amount as a mediator of the effects of intrinsic and extrinsic reading motivation on reading comprehension. Reading Research Quarterly, 48(4), 369-385. https://doi.org/10.1002/rгq.52

Schraw, G., \& Bruning, R. (1999). How implicit models of reading affect motivation to read and reading engagement. Scientific Studies of Reading, 3(3), 281-302. https://doi.org/10.1207/s1532799xssr0303 5

Stutz, F., Schaffner, E., \& Schiefele, U. (2016). Relations among reading motivation, reading amount, and reading comprehension in the early elementary grades. Learning and Individual Differences, 45, 101-113. https://doi.org/10.1016/j.lindif.2015.11.022 
Yusof, N. M. (2010). Influence of family factors on reading habits and interest among level 2 pupils in national primary schools in Malaysia. Procedia. Social and Behavioral Sciences, 5, 1160-1165.

https://doi.org/10.1016/j.sbspro.2010.07.253

Zebroff, D., \& Kaufman, D. (2017). Texting, reading, and other daily habits associated with adolescents' literacy levels. Education and Information Technologies, 22(5), 2197-2216. https://doi.org/10.1007/s10639$\underline{016-9544-3}$ 